\title{
REDUCTION POSSIBILITY OF PHOSPHORUS USING WITH THE APPLICATION OF MYCORRHIZA IN PURPLE CONEFLOWER (ECHINACEA PURPUREA L.) THROUGH PHYSIOLOGICAL TRAITS AND ESSENCE YIELD UNDER DIFFERENT IRRIGATION LEVELS
}

\author{
RAFAT, N. ${ }^{1}-$ YARniA, M. ${ }^{2 *}-$ MiRsheKARI, B. ${ }^{1}-$ RASHIDI, V. ${ }^{1}-$ MOGHADAM, A. M. D. ${ }^{3}$ \\ ${ }^{I}$ Department of Agriculture, Tabriz Branch, Islamic Azad University, Tabriz, Iran \\ ${ }^{2}$ Department of Agronomy, Faculty of Agriculture, Tabriz Branch, Islamic Azad University, \\ Tabriz, Iran \\ ${ }^{3}$ Department of Agriculture, Shabestar Branch, Islamic Azad University, Shabestar, Iran \\ *Corresponding author \\ e-mail:m.yarnia@yahoo.com \\ (Received $11^{\text {th }}$ Jun 2018; accepted $2^{\text {nd }}$ Aug 2018)
}

\begin{abstract}
The aim of this study was to investigate the effects of irrigation levels (irrigation after 70, 110 and $150 \mathrm{~mm}$ of pan evaporation), phosphorus fertilizer levels (non-application of phosphorus fertilizer and application of 25 and $50 \%$ of recommended doses) and different species of Mycorrhiza (nonapplication of mycorrhiza, application of Glomus intraradices, Glomus mossae, Glomus hoei and coapplication of the three species) on growth, essential oil production and physiological characteristics of medicinal plant, purple coneflower, in two crop years of 2015 and 2016. The study was performed in the form of split-split plot based on random block design. In most of the studied traits, decrease in water content for irrigation after 70 to $110 \mathrm{~mm}$ had no significant effect on vegetative traits and essential oil yield of purple coneflower. In irrigation after $150 \mathrm{~mm}$ of pan evaporation, despite a significant reduction of $44 \%$ in vegetative traits such as plant yield, the use of a number of fertilizer treatments, such as $50 \%$ of phosphorus application, combined with the application of mycorrhizal species and G. hoei species without phosphorus fertilizer, completely prevented the depressant effect of dehydration. In most of the traits, including wet and biological function per unit area, percentage of colonization, relative water content and aperture length, application of phosphorous fertilizer alone in full irrigation conditions (irrigation after $70 \mathrm{~mm}$ of pan evaporation), moderate dehydration (irrigation after $110 \mathrm{~mm}$ of pan evaporation) and severe dehydration (irrigation after $150 \mathrm{~mm}$ of pan evaporation), had no effect. The combined application of phosphorus and mycorrhiza fertilizer in irrigation after 70 and $150 \mathrm{~mm}$ of pan evaporation had no effect on the traits; however, at irrigation after $110 \mathrm{~mm}$ of pan evaporation, most of the treatment of combined application of phosphorus fertilizer and mycorrhiza increased significantly, especially in vegetative traits. Therefore, increase in the growth characteristics of purple coneflower at irrigation after $110 \mathrm{~mm}$ of pan evaporation with most fertilizer treatments did not affect these traits. The highest and lowest essential oil yields were obtained as 27.4 and $25.5 \mathrm{~g}$ in G. intraradices treatment with irrigation after $150 \mathrm{~mm}$ of pan evaporation and non-application of fertilizer with irrigation after $70 \mathrm{~mm}$ of pan evaporation. Considering the economic importance of the essential oil of purple coneflower, planting of this plant even in severe dehydration with the application of mycorrhiza may appear possible without reducing the essential oil yield, even though growth is negatively affected by dehydration.
\end{abstract}

Keywords: bio fertilizer, chemical fertilizer, drought, essential oil, physiological characteristic

\section{Introduction}

The purple coneflower (Echinacea purpurea L.), is an herbaceous and perennial plant. The active ingredients in the root and vegetative body of the various species of purple coneflower have anti-fungal, antibacterial and anti-viral properties. Medications 
for prevention and also treating cold and respiratory illnesses are prepared from this plant (Chevallier, 1996). Chemical fertilizers increase the growth and production of active ingredients in medicinal and crop plants. However, the excessive use of these fertilizers without soil degradation, combined with severe crop agronomic practices and adverse management, leads to instability in agriculture and serious threats to the health of underground resources, the destruction of microorganisms and insects, soil degradation and soil organic matter reduction (Pajooheshgar et al., 2015). Phosphorus is the essential food ingredient of plants which plays an important role in maximizing production in crops. The efficiency of phosphorus application in crops is between 10 and 30\% (Arshad et al., 2016). Reduction of inorganic phosphorus uptake is an appropriate strategy for reducing production cost. The application of mycorrhizal fungi is one of the suitable methods for reducing the amount of phosphorus consumed. The hypha massive fungi network effectively increases the absorption rate of the roots, allowing the plant to have more access to phosphorus. Phosphate ions are released into the heifers more rapidly than the roots, because they have a high tendency to absorb phosphorus in the hyphas and reduce threshold concentrations for absorption into the hyphas (Elbon and Valen, 2014). The results of several studies reveal the importance of mycorrhiza in helping plants with drought stress. One of the reasons for increasing resistance to stress is that, root colonization with mycorrhizal fungi in different plant species results in increased adsorption and proline production in drought stress conditions (Rapparini et al., 2013). Studies have shown that the effects of mycorrhizal fungi vary depending on the species of fungus. Das (2015) examined the type of mycorrhizal fungus in 12 herbal medicines and observed that, the type and intensity of fungal coexistence varied in different plants. Robinson et al. (2014) examined the effect of mycorrhiza on physiological growth and response of sesame. The application of mycorrhizal fungus enhanced the number of leaves, number of roots, the length of the aerial organ, the root biomass and chemical parameters. Total chlorophyll, chlorophyll $\mathrm{a}$, chlorophyll $\mathrm{b}$ and carotenoids also increased with the use of mycorrhizal fungi. Mohseni et al. (2015) investigated the effect of inoculation with mycorrhizal fungi on cumin, and showed that the application of mycorrhizal fungus increased the number of branches, shoot dry weight, root length, root fresh weight, root volume, root diameter, root dry weight, root length density and root surface. Considering the importance of less water consumption and increasing plant tolerance to it and the role of mycorrhiza in these conditions on one hand, and reduction of the use of phosphorus fertilizer in line with sustainable agricultural goals on the other hand, the aim of this study was to investigate the effects of mycorrhiza species on the reduction of phosphorus in low irrigation conditions and response of some of physiological traits and yield and yield components of essence in Purple Coneflower (Echinacea purpurea L.) to these factors.

\section{Materials and methods}

In order to evaluate the effect of different species of mycorrhiza at different levels of phosphorus fertilizer application on some morpho-physiological traits of purple coneflower in dehydration conditions, an experiment was performed at Agricultural Station of Islamic Azad University, Tabriz, Iran during two crop years of 2015 and 2016. This area is located $5 \mathrm{~km}$ from Tabriz, at longitude $46^{\circ}$ and $17^{\prime} \mathrm{E}$, latitude $38^{\circ}$ and $5^{\prime} \mathrm{N}$, and $1360 \mathrm{~m}$ above sea level. Based on the cluster classification of Dumontron, the region has a semi-arid cold climate. The average annual temperature is $10^{\circ} \mathrm{C}$, the average annual temperature is $16{ }^{\circ} \mathrm{C}$ and the mean annual temperature is $2.2^{\circ} \mathrm{C}$. The 
average annual precipitation in this area is $271.3 \mathrm{~mm}$ (Khalilvand and Yarnia, 2016). The soil $\mathrm{pH}$ of the region is in the weak alkaline range (Table 1).

Table 1. The results of physical and chemical analysis of the test site soil

\begin{tabular}{c|c|c|c|c|c|c|c|c|c}
\hline $\begin{array}{c}\text { Organic } \\
\text { carbon } \\
\text { percent }\end{array}$ & $\begin{array}{c}\text { Organic } \\
\text { matter } \\
\text { percent }\end{array}$ & Sand & Silt & Clay & $\begin{array}{c}\text { Conductivity } \\
(\mathbf{d s} / \mathbf{m})\end{array}$ & $\mathbf{p H}$ & $\mathbf{P}(\mathbf{p p m})$ & $\mathbf{K}(\mathbf{p p m})$ & $\begin{array}{c}\text { Potassium } \\
\text { solution } \\
(\mathbf{m g} / \mathbf{l})\end{array}$ \\
\hline 1.7 & 2.9 & 76 & 13 & 11 & 1.56 & 7.53 & 25.7 & 7.7 & 45 \\
\hline
\end{tabular}

The experiment was carried out as split-split plot in a completely randomized block design with three replications in two crop years of 2014 and 2015. The test factors include:

Different levels of dehydration as the main factor in three levels: Irrigation after $70 \mathrm{~mm}$ of evaporation from class A pan (control), irrigation after $110 \mathrm{~mm}$ of evaporation from class A pan (medium stress) and irrigation after $150 \mathrm{~mm}$ of evaporation from class A pan (severe stress). Phosphorus at three levels as a sub-factor: Non use of phosphorus, $25 \%$ and $50 \%$ recommended. The application rate of phosphorous fertilizer for treatment of 0 and $50 \%$ of the recommended dose was 25 and $50 \mathrm{~kg}$ of phosphorus fertilizer per hectare, respectively. Different species of mycorrhiza in five levels as sub-factor including: Non-use (control), Rhizophagus intraradices species ( $G$. intraradices), Funneliformis mosseae ( $G$. mossae), G. hoci species, and mixture of the three species.

For the test, land acquisition operations were performed in March 2014, with appropriate climatic conditions. After leveling the land, dimensions of $1.5 \times 2 \mathrm{~m}$ was applied on the plot. Each plot has three rows of irrigated crops and a stack of $45 \mathrm{~cm}$ in east-west direction. The spacing of the subplots was one-to-one plot, the main plots were $1.5 \mathrm{~m}$ and the distance between the two blocks was $2 \mathrm{~m}$. In early spring, after preparation of the land, different levels of phosphorus were applied based on the planting plan in the experimental plots. After the purple coneflower straws were prepared in mid-May, they were transported to the main land during the second to third leaf stages. Before planting, different strains of mycorrhiza (prepared from the Institute of Water and Soil) were based on the experimental map and $9 \mathrm{~g}$ were added to each straw. In the case of each mixed strain, $3 \mathrm{~g}$ were added to the planting site, and then transplantation was carried out. The straws were planted $30 \mathrm{~cm}$ apart from each other and in hot water stacks. Irrigation was done immediately after seedling. Irrigation was done every three to one day for the nesting. To combat weed, manual weeding was done at the required time. To supply nitrogen, $200 \mathrm{~kg} / \mathrm{ha}$ of urea was applied in two steps: half of the recommended amount was applied after nesting, and the other half was applied at the 8-10 leaf stage and before application of the aqueous treatments. After the first flowers emerged, dehydration stress was applied on the basis of irrigation after evaporation from class A pan. Each irrigation was done after $70 \pm 5,110 \pm 5$ and $150 \pm$ $5 \mathrm{~mm}$ of evaporation from class A pan. The daily evaporation rate of the pan, after reaching the desired amount for each treatment $(70,110$ and $150 \mathrm{~mm})$, indicated irrigation time.

The amount of irrigated water was calculated for each treatment based on the total water requirement, and by random sampling from three different parts of each plot and determining the percentage of soil water content; the amount was calculated at about 
$24 \mathrm{~h}$ before irrigation. To measure vegetative traits, 5 samples from each plot were harvested. To determine the vegetation factor, Equation 1 was used:

$$
\mathrm{ET}_{\mathrm{c}}=\mathrm{K}_{\mathrm{c}} \times \mathrm{ET}_{0} \text {, and } \mathrm{ET}_{0}=\mathrm{K}_{\mathrm{pan}} \times \mathrm{E}_{\mathrm{p}}
$$

where, ETC and ETO are the plant and reference evapotranspirations, Kpan and Ep are the pan coefficient, respectively (Allen et al., 1998; Fazeli Rostampour et al., 2013).

Total volumes of irrigation water applied in the control treatment (Irrigation after $70 \mathrm{~mm}$ of evaporation) were 4885.7 and $5026.4 \mathrm{~m}^{3}$ in 2015 and 2016 , respectively. The volume of water used in other treatments (irrigation after 110 and $150 \mathrm{~mm}$ of evaporation) were $3574.6,3685.4,2169.8$ and $2344.1 \mathrm{~m}^{3}$, respectively; so the lowest volume of water used in the irrigation after $150 \mathrm{~mm}$ of evaporation in 2015.

Relative water content (RWC) was obtained after determining fresh weight $(\mathrm{FW})$, saturation weight (TW) and dry weight (DW) of the 10 end leaves of the plant using the following formula (Eq.2; Levitt, 1980):

$$
R W C=\left(\frac{F W-D W}{T W-D W}\right) * 100
$$

To determine the biological yield, the specimens were kept in ventilated condition under shade conditions at room temperature for one month $\left(25^{\circ} \mathrm{C}\right)$ and after that, they were weighted with a weighing scale of $0.01 \mathrm{~g}$ and their average in grams was used in the study. Fresh weight of total organs of shoot (stem, leaf and flower) known shoot fresh weight. Flower shoots together with dried leaves in shade conditions were powdered using the mill and the essential oil was extracted by water distillation with Clevenger. A sample of $25 \mathrm{~g}$ of herbal powder was selected and it was put inside a balloon together with $5.00 \mathrm{ml}$ of distilled water. It was then heated by a Clevenger device for three hours. The yellow-colored essence was collected and the dehydration rate and essential oil percentage were determined using sodium water-free sodium sulfate and diethyl ether. The essential oil yield was obtained by multiplying dry matter yield by essential oil percentage.

The Arnon method (1949) was used to determine the amount of chlorophyll a, b and total chlorophyll, and carotenoids content in mg per grams of fresh leaf weight $(E q .3)$. For this purpose, $0.5 \mathrm{~g}$ of fresh leaves was washed with $5 \mathrm{ml}$ of acetone $80 \%(W / V)$. After $15 \mathrm{~min}$ of centrifugation at $1000 \mathrm{rpm}$ per minute and $4{ }^{\circ} \mathrm{C}$, it reached $10 \mathrm{ml}$. The absorbance of the extract was read by spectrophotometer at 663, 645, 510 and $480 \mathrm{~nm}$ wavelengths and the following relationships were used to measure the parameters. In these relationships, $\mathrm{C}$ is chlorophyll, $\mathrm{A}$ is the wavelength, $\mathrm{V}$ is the volume of solution, and $\mathrm{W}$ is the leaf sample weight.

$$
\begin{aligned}
& \mathrm{C}_{\mathrm{a}}=12.7\left(\mathrm{~A}_{663}\right)-2.69\left(\mathrm{~A}_{645}\right) \times \mathrm{V} / \mathrm{P} 50 \% \mathrm{M} 0 \mathrm{~W} \\
& \mathrm{C}_{\mathrm{b}}=22.9\left(\mathrm{~A}_{645}\right)-2.69\left(\mathrm{~A}_{663}\right) \times \mathrm{V} / \mathrm{P} 50 \% \mathrm{M} 0 \mathrm{~W} \\
& \mathrm{C}_{\mathrm{T}}=20.2\left(\mathrm{~A}_{645}\right)+8.02\left(\mathrm{~A}_{663}\right) \times \mathrm{V} / \mathrm{P} 50 \% \mathrm{M} 0 \mathrm{~W} \\
& \text { Carotenoid }=7.6\left(\mathrm{~A}_{480}\right)-14.9\left(\mathrm{~A}_{510}\right) \times \mathrm{V} / \mathrm{P} 50 \% \mathrm{M} 0 \mathrm{~W}
\end{aligned}
$$


For assessment of the stability of cytoplasmic membrane, ion leakage measurement method was employed using a conductivity meter.

Statistical data analysis was performed based on statistical model of split-split plot test using SAS 9.1 software and the mean of the treatments was compared by Duncan's multi-range test method at 5\% level. Diagrams were obtained with Excel software.

\section{Results and discussion}

The effects of experimental factors and compounds on the traits evaluated are presented in Table 2.

\section{Number of flowering branches}

In this study, interaction between the levels of irrigation and phosphorus fertilizers and interaction between levels of phosphorus fertilizer and mycorrhizal fertilizer treatment with regards to the number of flowering branches were significant (Table 2). Under irrigation conditions, change in irrigation water after 70 to $150 \mathrm{~mm}$ of pan evaporation had no significant effect on the number of flowering branches in the purple coneflower. Nevertheless, consumption of $25 \%$ of the recommended dose of phosphorus fertilizer with irrigation after $150 \mathrm{~mm}$ pan evaporation, the number of flowering branches as compared to irrigation after $70 \mathrm{~mm}$ pan evaporation was higher by $31.4 \%$; this reaction appears to be due to an incremental effect of $25 \%$ of recommended dose of phosphorus fertilizer. In this study, number of flowering branches increased in consumption of 25 and $50 \%$ of the recommended dose of phosphorus with reduced water irrigation after 70 and $150 \mathrm{~mm}$ of pan evaporation (Fig. 1). Research has shown that dehydration reduces the number of branches produced; one of the main reasons is decrease in the amount and activity of the hormone, cytokine (DaCosta and Huang, 2007). The cytokine hormone plays an important role in the formation of side stems (Miyawaki et al., 2004). According to Evers et al. (2011), the branching depends on the presence of assimilates. While dryness reduces assimilate content in the plant (Ash et al., 2001), phosphorus that plays an important role in photosynthesis, production of photosynthetic materials and their transfer to various parts of plants, reduces the effects of dryness reduction (Khan et al., 2013; Hammond and White, 2008). Kotoky et al. (2015) also observed that application of phosphorus fertilizer significantly increases the number of branches produced in Aristolochia indica plant.

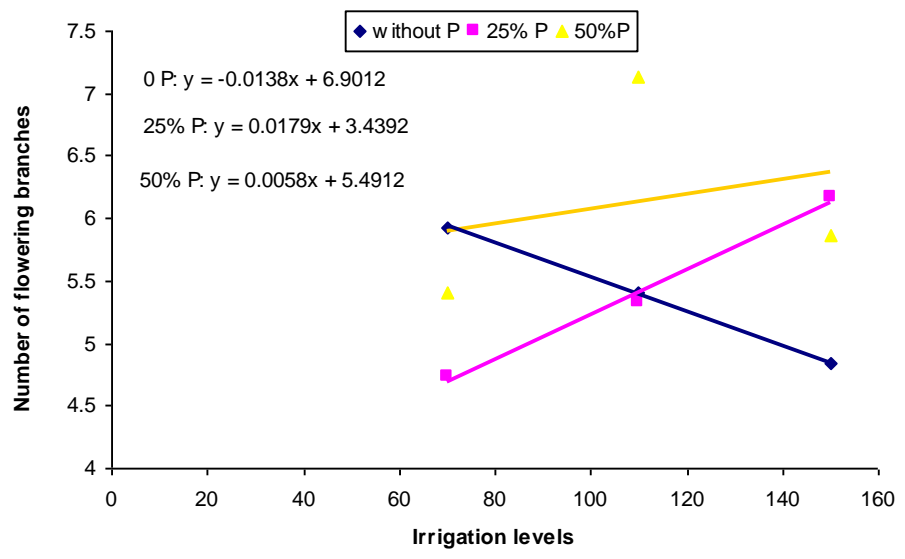

Figure 1. Effect of phosphorous on number of flowering branches under irrigation levels 
Table 2a. Combined variance analysis of studied traits in purple coneflower

\begin{tabular}{|c|c|c|c|c|c|c|c|c|c|}
\hline S.O.V. & DF & $\begin{array}{c}\text { Number } \\
\text { of } \\
\text { flowering } \\
\text { branches }\end{array}$ & $\begin{array}{l}\text { Biological } \\
\text { yield }\end{array}$ & $\begin{array}{c}\text { Shoot } \\
\text { fresh } \\
\text { weight }\end{array}$ & $\begin{array}{c}\text { Leaf } \\
\text { area } \\
\text { index }\end{array}$ & $\begin{array}{l}\text { Essence } \\
\text { percent }\end{array}$ & $\begin{array}{l}\text { Essence } \\
\text { yield }\end{array}$ & $\begin{array}{c}\text { Chlorophyll } \\
\text { a content }\end{array}$ & $\begin{array}{c}\text { Chlorophyll } \\
\text { b content }\end{array}$ \\
\hline Year (y) & 1 & 274.01 ** & 8122.57 & 3719.05 & $28.42 * *$ & $0.99 *$ & 6.57 & 4.92 & 1253501 \\
\hline Error 1 & 4 & 5.94 & 4047.67 & 767.84 & 0.36 & 0.1 & $15.53 * *$ & $18.43 * *$ & $579642 * *$ \\
\hline Irrigation levels (A) & 2 & 16.14 & $106103 * * *$ & $199331 * *$ & 0.22 & 0.08 & $13.91 *$ & 22.3 & 89628.04 \\
\hline $\mathrm{Y} * \mathrm{~A}$ & 2 & 5.62 & 1074.56 & 77.73 & 0.09 & 0.2 & 0.18 & 0.141 & 87870.36 \\
\hline Error 2 & 8 & $12.401 *$ & 1627.03 & 1155.09 & 0.14 & 0.1 & 2.31 & $9.77 * *$ & $71788 * *$ \\
\hline Phosphorus fertilizer levels (B) & 2 & 8.133 & 5626.17 & $5140.49^{*}$ & 0.1 & $0.42 *$ & 4.09 & $8.866^{*}$ & 1985.786 \\
\hline Mycorrhizal specie (C) & 4 & 12.58 & $10092 * *$ & $9438.85 * *$ & 0.02 & 0.04 & 4.36 & 4.97 & $5709^{*}$ \\
\hline $\mathrm{A} * \mathrm{~B}$ & 4 & $20.311 * *$ & $7775.09 * *$ & $39542 * *$ & $0.39 *$ & 0.31 & 4.42 & $10.469 * *$ & 2309.149 \\
\hline $\mathrm{A} * \mathrm{C}$ & 8 & 10.153 & $5762.5^{*}$ & $12513.2 * *$ & 0.13 & 0.11 & $9.38 * *$ & 1.77 & 1283.794 \\
\hline $\mathrm{B} * \mathrm{C}$ & 8 & $11.75^{*}$ & $5722.01 *$ & $4390.61 * *$ & $0.38 *$ & $0.31 *$ & 2.66 & 3.8 & 2491.6 \\
\hline $\mathrm{A} * \mathrm{~B} * \mathrm{C}$ & 16 & 6.36 & $5313 * *$ & $4604.74 * *$ & 0.2 & 0.17 & 3.35 & 3.062 & 2799.168 \\
\hline $\mathrm{Y} * \mathrm{~B}$ & 2 & 6.45 & 1389.646 & 36.2 & 0.002 & 0.17 & 0.22 & 0.022 & 1690.288 \\
\hline $\mathrm{Y} * \mathrm{c}$ & 4 & 1.24 & 1660.921 & 33.89 & 0.29 & 0.03 & 0.39 & 0.11 & 4323.631 \\
\hline $\mathrm{Y} * \mathrm{~B} * \mathrm{C}$ & 8 & 1.2 & 1508.031 & 2.65 & 0.21 & 0.06 & 0.38 & 0.19 & 1871.82 \\
\hline $\mathrm{Y} * \mathrm{~A} * \mathrm{~B}$ & 4 & 2.3 & 1410.989 & 13.41 & 0.1 & 0.01 & 0.2 & 0.0796 & 1528.395 \\
\hline $\mathrm{Y} * \mathrm{~A} * \mathrm{C}$ & 8 & 1.35 & 1366.123 & 7.89 & 0.1 & 0.1 & 0.3 & 0.249 & 1022.415 \\
\hline $\mathrm{Y} * \mathrm{~A} * \mathrm{~B} * \mathrm{C}$ & 16 & 0.81 & 1420.476 & 21.83 & 0.05 & 0.035 & 0.43 & 0.24 & 1833.318 \\
\hline Error 3 & 168 & 5.34 & 2221.842 & 1104.86 & 0.15 & 0.13 & 3.48 & 2.78 & 2099.487 \\
\hline $\mathrm{CV}(\%)$ & & 40.95 & 32.97306 & 17.18 & 11.68 & 7.89 & 7.04 & 8.8 & 44.607 \\
\hline
\end{tabular}

*and $* *$, respectively, represent significance at the probability level of 1 and $5 \%$

Table $2 \boldsymbol{b}$. Combined variance analysis of studied traits in purple coneflower (continued)

\begin{tabular}{|c|c|c|c|c|c|c|c|c|}
\hline S.O.V. & DF & $\begin{array}{l}\text { Carotenoid } \\
\text { content }\end{array}$ & $\begin{array}{c}\text { Plasma } \\
\text { membrane } \\
\text { stability }\end{array}$ & $\begin{array}{c}\text { Root } \\
\text { colonization }\end{array}$ & $\begin{array}{l}\text { Stoma } \\
\text { length }\end{array}$ & $\begin{array}{l}\text { Stoma } \\
\text { width }\end{array}$ & $\begin{array}{c}\text { Relative } \\
\text { water } \\
\text { content }\end{array}$ & $\begin{array}{c}\text { Stoma } \\
\text { resistance }\end{array}$ \\
\hline Year (y) & 1 & 4.802667 & 152.62 & 1737.87 & 34.13 & 2.314 & 54.8 & 25.42 \\
\hline Error 1 & 4 & $6.12 * *$ & $39.67 * *$ & $722.11 * *$ & $11.4 * *$ & $13.56 * *$ & 56.86 & $11.08 * *$ \\
\hline Irrigation levels (A) & 2 & 7.67 & 8.55 & 47.11 & 1.35 & 2.8 & 99.27 & 45.08 \\
\hline $\mathrm{Y} * \mathrm{~A}$ & 2 & 0.0008 & 4.58 & 41.55 & 2.01 & 0.72 & 9.05 & 1.8 \\
\hline Error 2 & 8 & $5 * *$ & $18.64 *$ & 37.09 & 1.12 & $5.25 * *$ & 50.1 & $12.89 * *$ \\
\hline Phosphorus fertilizer levels (B) & 2 & 3.29 & 18.69 & 294.81 & 0.1 & 2.23 & 3.23 & $13.03 *$ \\
\hline Mycorrhizal specie (C) & 4 & $4.5^{*}$ & 4.53 & $758.96 * *$ & $3.24 *$ & $2.45^{*}$ & $525.61 * *$ & 3.2 \\
\hline $\mathrm{A} * \mathrm{~B}$ & 4 & $5.39 *$ & 5.34 & $713.84 * *$ & 1.32 & $3.76^{*}$ & $311.86^{* *}$ & 6.09 \\
\hline$A * C$ & 8 & 2.975 & 7.18 & 176.7 & $3.34 * *$ & $3.32 * *$ & 191.93* & 4.1 \\
\hline $\mathrm{B} * \mathrm{C}$ & 8 & $4.101 *$ & 13.42 & $608.15^{* *}$ & 1.02 & $3.29 * *$ & 157.9 & 5.18 \\
\hline $\mathrm{A} * \mathrm{~B} * \mathrm{C}$ & 16 & $4.18 * *$ & $27.27 * *$ & $575.35^{* *}$ & $2.16^{*}$ & $2.76^{* *}$ & $347.78 * *$ & 3.83 \\
\hline $\mathrm{Y} * \mathrm{~B}$ & 2 & 0.016 & 3.803704 & 1.48 & 0.17 & 0.27 & 2.72 & 2.19 \\
\hline $\mathrm{Y} * \mathrm{c}$ & 4 & 0.015 & 1.41 & 5.25 & 0.23 & 0.16 & 2.37 & 1.97 \\
\hline $\mathrm{Y} * \mathrm{~B} * \mathrm{C}$ & 8 & 0.009 & 0.88 & 7.78 & 0.80 & 0.4 & 2.37 & 1.19 \\
\hline $\mathrm{Y} * \mathrm{~A} * \mathrm{~B}$ & 4 & 0.06 & 2.47 & 10.9537 & 0.32 & 0.11 & 2.75 & 1.25 \\
\hline $\mathrm{Y} * \mathrm{~A} * \mathrm{C}$ & 8 & 0.052 & 2.88 & 1.61 & 0.72 & 0.14 & 2.76 & 1.84 \\
\hline $\mathrm{Y} * \mathrm{~A} * \mathrm{~B} * \mathrm{C}$ & 16 & 0.054 & 1.36 & 8.75 & 1.62 & 0.23 & 2.01 & 1.41 \\
\hline Error 3 & 168 & 1.609 & 7.96 & 109.32 & 1.21 & 1.24 & 89.91 & 2.85 \\
\hline $\mathrm{CV}(\%)$ & & 25.361 & 12.51 & 28.1 & 17.12 & 27.96 & 23.64 & 51.12 \\
\hline
\end{tabular}

*and $* *$, respectively, represent significance at the probability level of 1 and $5 \%$ 
In this study, among the fertilizer treatment combinations, the highest number of flowering branches with $7.3 \%$ was obtained in the treatment of $25 \%$ recommended phosphorus dose combined with the mixture of all mycorrhiza species; the lowest was 4.1 which was associated with $G$. hoei application without phosphorus fertilizer application. In the present study, with $25 \%$ of recommended phosphorus fertilizer dose, the application of mycorrhiza fertilizer, and also in mixture, a significant increase of $48.9 \%$ in the number of purple coneflower branches was observed (Table 3). The most important role of mycorrhizal fungi is in increasing phosphorus absorption (Yadav and Aggarwal, 2015). Application of mycorrhiza increases phosphorus effect on plant branching by increasing plant access to phosphorus. Increasing phosphorus absorption via the use of fungi can increase the number of side flowering branches by increasing the production of assimilates. On the other hand, these microorganisms play an important role in the morphology of plants by releasing growth stimulants such as auxin and cytokine (Salvucci et al., 2010).

Table 3. Comparison of the mean of studied traits under the influence of phosphorous fertilizer levels and mycorrhizal fungi species

\begin{tabular}{|c|c|c|c|c|c|}
\hline $\begin{array}{c}\text { Phosphorus fertilizer } \\
\text { levels (\% of desired } \\
\text { dose) }\end{array}$ & Mycorrhiza specie & $\begin{array}{c}\text { Number of } \\
\text { flowering } \\
\text { branches }\end{array}$ & Leaf area index & $\begin{array}{c}\text { Essential oil } \\
\text { percentage }\end{array}$ & Essential oil yield \\
\hline Non-use of phosphorus & Control & $6.722 \mathrm{ab}$ & $3.444 \mathrm{abc}$ & $4.867 \mathrm{a}$ & $25.24 \mathrm{~b}$ \\
\hline Non-use of phosphorus & G. intraradices & $5.056 \mathrm{bcd}$ & $3.432 \mathrm{abc}$ & $4.733 \mathrm{abc}$ & $26.12 \mathrm{ab}$ \\
\hline Non-use of phosphorus & G. mossae & $5.500 \mathrm{bcd}$ & $3.251 \mathrm{abc}$ & $4.729 \mathrm{abc}$ & $27.38 \mathrm{a}$ \\
\hline Non-use of phosphorus & G. hoei & $4.167 \mathrm{~d}$ & $3.326 \mathrm{abc}$ & $4.623 \mathrm{abc}$ & $27.03 \mathrm{ab}$ \\
\hline Non-use of phosphorus & Mixture of three species & $5.333 \mathrm{bcd}$ & $3.524 \mathrm{ab}$ & $4.600 \mathrm{abc}$ & $25.35 \mathrm{~b}$ \\
\hline 25 & Control & $4.944 \mathrm{bcd}$ & $3.419 \mathrm{abc}$ & $4.689 \mathrm{abc}$ & $26.82 \mathrm{ab}$ \\
\hline 25 & G. intraradices & $6.167 \mathrm{abc}$ & $3.369 \mathrm{abc}$ & $4.533 \mathrm{bc}$ & $26.36 \mathrm{ab}$ \\
\hline 25 & G. mossae & $5.444 \mathrm{bcd}$ & $3.271 \mathrm{abc}$ & $4.778 \mathrm{ab}$ & $26.52 \mathrm{ab}$ \\
\hline 25 & G. hoei & 5.889 abcd & $3.229 \mathrm{bc}$ & $4.878 \mathrm{a}$ & $26.31 \mathrm{ab}$ \\
\hline 25 & Mixture of three species & $7.333 \mathrm{a}$ & $3.348 \mathrm{abc}$ & $4.689 \mathrm{abc}$ & $25.76 \mathrm{ab}$ \\
\hline 50 & Control & $6.444 \mathrm{abc}$ & $3.163 \mathrm{c}$ & $4.467 \mathrm{c}$ & $27.26 \mathrm{a}$ \\
\hline 50 & G. intraradices & $5.611 \mathrm{abcd}$ & $3.277 \mathrm{abc}$ & $4.611 \mathrm{abc}$ & $27.45 \mathrm{a}$ \\
\hline 50 & G. mossae & $5.389 \mathrm{bcd}$ & $3.544 \mathrm{a}$ & $4.543 \mathrm{bc}$ & $26.27 \mathrm{ab}$ \\
\hline 50 & G. hoei & $4.833 \mathrm{~cd}$ & $3.532 \mathrm{ab}$ & $4.611 \mathrm{abc}$ & $26.80 \mathrm{ab}$ \\
\hline 50 & Mixture of three species & $5.833 \mathrm{abcd}$ & $3.335 \mathrm{abc}$ & $4.733 \mathrm{abc}$ & $27.03 \mathrm{ab}$ \\
\hline
\end{tabular}

Means with different letters in each column have significant difference at $5 \%$ probability level.

\section{Leaf area index}

In this study, the highest leaf area index (3.5) was related to non-use of phosphorus fertilizer with irrigation after $70 \mathrm{~mm}$ of pan evaporation, and the lowest (3.1) was associated with non-use of phosphorus chemical fertilizer and irrigation after 150 of the pan evaporation. Dehydration at levels of 25 and $50 \%$ of recommended phosphorus fertilizer dose did not have a significant effect on leaf area index of purple coneflower leaves. In the case of non-application of phosphorus fertilizer, water reduction with irrigation after 70 to $150 \mathrm{~mm}$ of pan evaporation reduced the leaf area index to $11.4 \%$ (Fig. 2). According to the results of this study, application of phosphorus prevented the reduction of leaf areas in low-irrigation conditions. The positive effect of phosphorus fertilizer application on the increase of plant tolerance to dehydration in terms of leaf growth has been also reported by Jamali (2013) in Coriandrum sativum herb. Phosphorus 
is an essential nutrient for leaf growth, which plays an important role in the production of new leaves and increase of the area of each leaf in plants (Fletcher et al., 2004; Trindade et al., 2010). Anatomical studies have revealed that, using phosphorus fertilizer increases the length of leaf cells which increases leaf growth (Esmail et al., 2014).

In the present study, the maximum leaf area index was $3.5 \%$ for $50 \%$ of recommended dose of phosphorus fertilizer with $G$. mossae, and the lowest was associated with the application of $25 \%$ of recommended dose of phosphorus fertilizer without mycorrhiza application. At phosphorus fertilizer level of $25 \%$ and nonapplication of phosphorus fertilizer, none of the mycorrhizal treatments had a significant effect on leaf area index of purple coneflower. Nevertheless, in application of $50 \%$ of recommended phosphorus fertilizer dose, the application of G. mossae increased the leaf area index of purple coneflower by $7.8 \%$ (Table 3). The positive effect of mycorrhiza on the growth of plant leaves has been also reported by other researchers. In a study conducted on Coriaria nepalensis, Bargali and Bargali (2009) observed that, the application of mycorrhiza causes a 17\% increase in the leaf area of $C$. nepalensis. In the present study, differences were observed between the studied species of mycorrhiza in terms of effectiveness on leaf area index. Kumar et al. (2009) in a study, evaluated the effects of two types of mycorrhizal fungi on Salvia officinalis growth and there was a significant difference between the species of mycorrhizal fungi in terms of leaf area. Thus, one of the species increased leaf area of $S$. officinalis by $45 \%$, and G. mossae increased the leaf area of peppermint by $85 \%$.

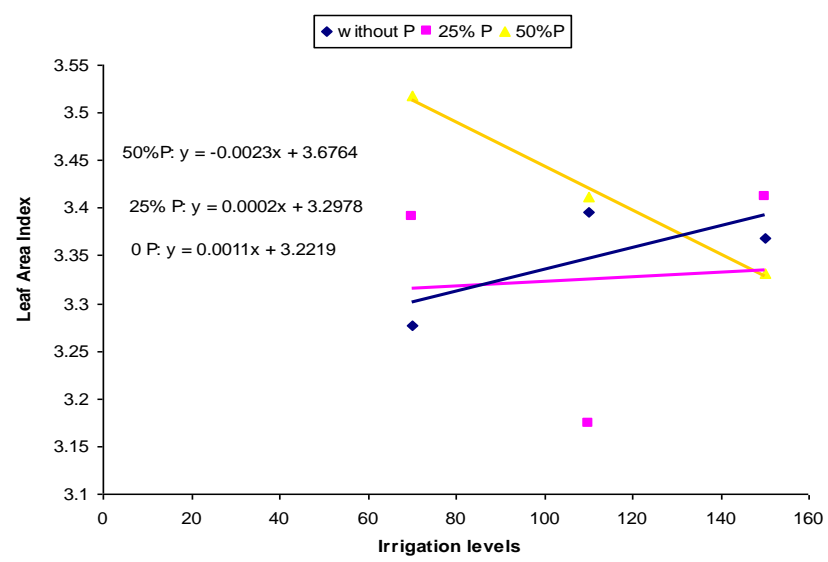

Figure 2. Effect of phosphorous on leaf area index under irrigation levels

\section{Essential oil yield and percentage}

In this study, the highest percentage of essential oil was related $25 \%$ of recommended dose of phosphorus fertilizer and $G$. hoei, and the lowest value was associated with $50 \%$ of recommended dose of phosphorus fertilizer alone. In this study, in the case of non-application of mycorrhiza, $50 \%$ of the recommended dose decreased the percentage of purple coneflower essential oil by $8.3 \%$; however, with the use of mycorrhiza, no reduction was found in the percentage of essential oil due to the application of phosphorous fertilizer (Fig. 3). Similar results have been obtained by Hosseini Valiki et al. (2015) for Rosemary plant and Le et al. (2013) for Salvia miltiorrhiza. Lo et al. (2013) stated that probably, under conditions of increased phosphorus fertilizer levels, growth and early metabolism of the plant were more 
affected by phosphorus fertilization and consequently, the production of essential oils in medicinal herbs reduced.

The highest and lowest essential oil yield per unit area was 27.4 and $25.5 \mathrm{~g}$ in $G$. intraradices treatments with irrigation after $150 \mathrm{~mm}$ of pan evaporation and nonapplication of the fertilizer after $70 \mathrm{~mm}$ of pan evaporation. In this study, an increase of $7.9 \%$ was observed in essential oil yield per square meter in only non-application of mycorrhiza with reduced water irrigation after 70 and $150 \mathrm{~mm}$ of pan evaporation (Fig. 3). In addition, among the fertilizer treatments, G. mossae fertilizer treatment alone, $50 \%$ recommended phosphorus fertilizer alone and $50 \%$ of recommended dose of phosphorus fertilizer with $G$. intraradices significantly increased the essential oil yield; however, other fertilizer compounds did not have a significant effect on the yield of essential oil. Therefore, the effect of application of fertilizer on essential oil yield depends on mycorrhiza species and phosphorus level. Habibzadeh (2015) reported that the degree of coexistence of different mycorrhiza species with plants is different at different levels of phosphorus fertilizer; this is due to structural and secretion changes of the roots at different levels of chemical phosphorus fertilization. In the present study, high levels of phosphorus fertilizer with application of mycorrhiza species alone reduced essential oil content. At high levels of phosphorus fertilizer application, the amount of carbohydrate secretion from plant roots decreased and the thickness of the epidermis layer of the root increased which reduced the coexistence of fungi with plants (Habibzadeh, 2015).

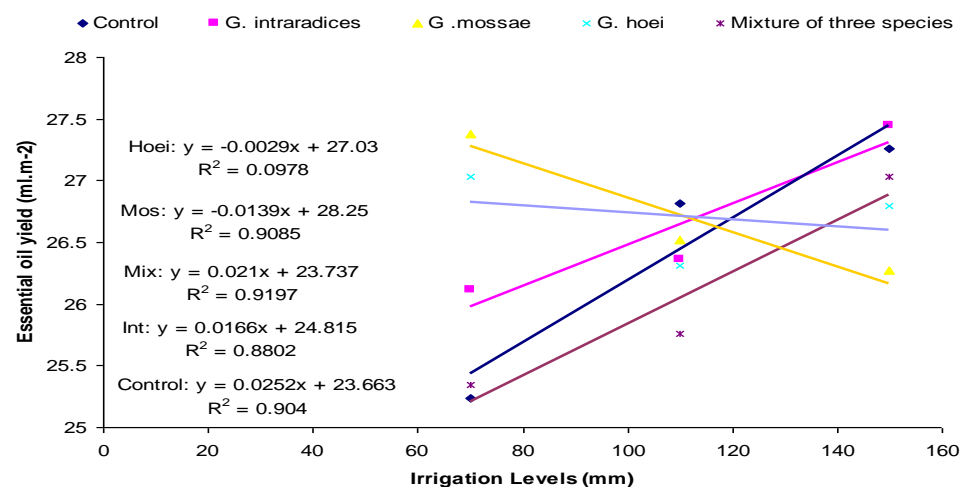

Figure 3. Effect of mycorhiza on essential oil yield under irrigation levels

\section{Percentage of colonization}

The highest percentage of root colonization of 58.6\% was observed in the treatment of $G$. intraradices alone and with irrigation after $110 \mathrm{~mm}$ of pan evaporation and the lowest $(21.33 \%)$ in the application of $25 \%$ of recommended dose of phosphorus fertilizer with $G$. hoei was obtained for irrigation after $150 \mathrm{~mm}$ of pan evaporation. According to the results obtained from this study, dehydration had a significant effect on the percentage of root colonization in G. mossae treatment alone. In the application of G. mossae alone, by decreasing irrigation water, $32.5 \%$ of root colonization was reduced (Table 3). At irrigation level after $150 \mathrm{~mm}$ of evaporation, fertilizer treatment had no significant effect on the root colonization percentage. At irrigation level after $110 \mathrm{~mm}$ of pan evaporation of some fertilizer treatments, a significant increase was observed in percentage of root colonization. At irrigation level after evaporation of $110 \mathrm{~mm}$ from the evaporation pan, application of $G$. intraradices and $G$. mossae 
treatments alone and $25 \%$ of recommended dose of phosphorus fertilizer in addition to G. hoei, increased this trait by $93.4,87.9$ and $74.2 \%$, respectively. According to the results, the $G$. intraradices species can be considered as a superior species in the establishment of coexistence with purple coneflower.

\section{Biological yield and shoot fresh weight}

In this study, the highest wet and biological yields were obtained as 303.6 and $235 \mathrm{~g}$ in $50 \%$ of recommended dose of phosphorus fertilizer with G. mossae and irrigation after $70 \mathrm{~mm}$ of pan evaporation. The lowest wet and biological yields were observed as 108 and $65.4 \mathrm{~g}$, respectively, in treatments with $50 \%$ of recommended dose of phosphorus fertilizer together with $G$. hoei and $50 \%$ of recommended dose of phosphorus fertilizer with a mixture of mycorrhizal fertilizers at irrigation after $150 \mathrm{~mm}$ of pan evaporation. From the results, irrigation water reduction had negative effect on wet and biological yields per square meter. With decrease in irrigation water from after 70 to $150 \mathrm{~mm}$ of pan evaporation, the highest reduction of $62.4 \%$ was achieved in the application of $25 \%$ of recommended dose of phosphorus fertilizer alone. Nevertheless, in the fertilizer mixture of $G$. intraradices, G. hoei and a mixture of fertilizers alone and $25 \%$ of recommended dose of phosphorus fertilizer with $G$. intraradices, dehydration did not affect the wet and biological yields (Table 4). Research has shown that by decreasing irrigation water, the accumulation of dry matter and the rate of water absorption reduces (Nazarli and Zardashti, 2010). The absorption of water and food in the plant is dependent on the activity of the roots, and in the case of dehydration, root growth and absorption activity of the roots will be reduced (Boomsma and Wyn, 2008). On the other hand, decrease in dry weight due to dehydration can be as a result of reduced assimilate production and the capacity to absorb assimilates for growth (Yardanova and Popova, 2007).

Table 4. Comparison of the mean of studied traits under the influence of irrigation levels, phosphorus fertilizer levels and mycorrhizal fungal species

\begin{tabular}{|c|c|c|c|c|c|c|c|c|c|c|}
\hline $\begin{array}{c}\text { Irrigation } \\
\text { levels }(\mathbf{m m} \\
\text { of pan }\end{array}$ & \begin{tabular}{|c|} 
Phosphorus \\
fertilizer \\
levels (\% of \\
optimal dose)
\end{tabular} & $\begin{array}{c}\text { Mycorrhiza } \\
\text { specie }\end{array}$ & $\begin{array}{c}\text { Root } \\
\text { colonization } \\
(\%)\end{array}$ & $\begin{array}{c}\text { Plasma } \\
\text { membran } \\
\text { e stability }\end{array}$ & $\begin{array}{l}\text { Shoot fresh } \\
\text { weight } \\
\text { (g/plant) }\end{array}$ & $\begin{array}{c}\text { Biological } \\
\text { yield }\left(\mathrm{g} / \mathrm{m}^{2}\right)\end{array}$ & $\begin{array}{c}\text { Carotenoid } \\
(\mathrm{mg} / \mathrm{g})\end{array}$ & RWC (\%) & $\begin{array}{c}\text { Stoma } \\
\text { length } \\
(\mathrm{mm})\end{array}$ & $\begin{array}{l}\text { Stoma } \\
\text { width } \\
(\mathrm{mm})\end{array}$ \\
\hline \multirow{20}{*}{70} & \multirow{5}{*}{0} & Control & $47.50 \mathrm{a}-\mathrm{e}$ & $17.83 \mathrm{c}$ & $258.4 \mathrm{a}-\mathrm{d}$ & $162.1 \mathrm{a}-\mathrm{h}$ & $3.417 \mathrm{e}$ & $48.49 \mathrm{abc}$ & $5.833 \mathrm{~cd}$ & $4.000 \mathrm{a}-\mathrm{e}$ \\
\hline & & G. intradices & $54.33 \mathrm{abc}$ & $22.33 \mathrm{abc}$ & $201.1 \mathrm{~d}-\mathrm{i}$ & $141.0 \mathrm{~b}-\mathrm{k}$ & $3.665 \mathrm{de}$ & $48.09 \mathrm{a}-\mathrm{d}$ & $6.167 \mathrm{bcd}$ & $4.333 \mathrm{a}-\mathrm{e}$ \\
\hline & & G. mossae & $28.00 \mathrm{e}-\mathrm{i}$ & $25.17 \mathrm{ab}$ & $277.7 \mathrm{ab}$ & $169.7 \mathrm{a}-\mathrm{h}$ & $3.783 \mathrm{cde}$ & $34.82 \mathrm{~b}-\mathrm{g}$ & $7.000 \mathrm{abc}$ & $4.333 \mathrm{a}-\mathrm{e}$ \\
\hline & & G. hoei & $22.00 \mathrm{hi}$ & $25.50 \mathrm{a}$ & $212.8 \mathrm{c}-\mathrm{h}$ & $164.1 \mathrm{a}-\mathrm{h}$ & 5.160 a-e & $37.59 \mathrm{~b}-\mathrm{g}$ & $6.167 \mathrm{bcd}$ & $5.167 \mathrm{abc}$ \\
\hline & & Mix & $28.67 \mathrm{e}-\mathrm{i}$ & $22.83 \mathrm{abc}$ & $170.2 \mathrm{~g}-\mathrm{m}$ & $156.3 \mathrm{a}-\mathrm{i}$ & 5.347 a-e & $42.59 \mathrm{a}-\mathrm{f}$ & $6.833 \mathrm{abc}$ & $5.667 \mathrm{a}$ \\
\hline & \multirow{5}{*}{25} & Control & $30.67 \mathrm{e}-\mathrm{i}$ & $22.17 \mathrm{abc}$ & $257.5 \mathrm{a}-\mathrm{d}$ & $169.1 \mathrm{a}-\mathrm{h}$ & $6.060 \mathrm{abc}$ & $41.59 \mathrm{a}-\mathrm{g}$ & $5.667 \mathrm{~cd}$ & 3.667 a-e \\
\hline & & G. intradices & $26.17 \mathrm{f}-\mathrm{i}$ & $20.67 \mathrm{abc}$ & $185.5 \mathrm{f}-\mathrm{l}$ & 139.5 b-k & $4.648 \mathrm{a}-\mathrm{e}$ & $41.96 \mathrm{a}-\mathrm{g}$ & $4.833 \mathrm{~d}$ & $3.167 \mathrm{cde}$ \\
\hline & & G. mossae & $44.50 \mathrm{a}-\mathrm{f}$ & $20.83 \mathrm{abc}$ & $267.3 \mathrm{abc}$ & $180.1 \mathrm{a}-\mathrm{f}$ & $5.493 \mathrm{a}-\mathrm{e}$ & $40.81 \mathrm{a}-\mathrm{g}$ & $7.500 \mathrm{ab}$ & $4.500 \mathrm{a}-\mathrm{d}$ \\
\hline & & G. hoei & $52.33 \mathrm{a}-\mathrm{d}$ & $23.17 \mathrm{ab}$ & $216.3 \mathrm{c}-\mathrm{h}$ & $172.4 \mathrm{a}-\mathrm{g}$ & $4.600 \mathrm{a}-\mathrm{e}$ & $28.16 \mathrm{fg}$ & $6.833 \mathrm{abc}$ & $5.333 \mathrm{ab}$ \\
\hline & & Mix & $31.00 \mathrm{e}-\mathrm{i}$ & $23.67 \mathrm{ab}$ & $203.2 \mathrm{~d}-\mathrm{i}$ & $141.5 \mathrm{~b}-\mathrm{k}$ & $4.362 \mathrm{a}-\mathrm{e}$ & $43.99 \mathrm{a}-\mathrm{f}$ & $5.667 \mathrm{~cd}$ & $4.000 \mathrm{a}-\mathrm{e}$ \\
\hline & \multirow{5}{*}{50} & Control & $28.00 \mathrm{e}-$ & $24.00 \mathrm{ab}$ & $268.8 \mathrm{abc}$ & $199.5 \mathrm{abc}$ & $5.813 \mathrm{a}-\mathrm{d}$ & 43.72 a-f & $6.667 \mathrm{abc}$ & 3.667 a-e \\
\hline & & G. intradices & $41.50 \mathrm{a}-\mathrm{g}$ & $24.17 \mathrm{ab}$ & $188.4 \mathrm{e}-\mathrm{k}$ & $149.6 \mathrm{a}-\mathrm{k}$ & $6.093 \mathrm{abc}$ & $32.56 \mathrm{c}-\mathrm{g}$ & $7.167 \mathrm{abc}$ & $4.500 \mathrm{a}-\mathrm{d}$ \\
\hline & & G mossae & $35.50 \mathrm{c}-\mathrm{i}$ & $21.00 \mathrm{abc}$ & $303.6 \mathrm{a}$ & $235.8 \mathrm{a}$ & $3.273 \mathrm{e}$ & $32.26 \mathrm{c}-\mathrm{g}$ & $7.000 \mathrm{abc}$ & $5.167 \mathrm{abc}$ \\
\hline & & G. hoei & $41.00 \mathrm{a}-\mathrm{h}$ & $20.00 \mathrm{bc}$ & $193.6 \mathrm{e}-\mathrm{j}$ & $142.3 \mathrm{~b}-\mathrm{k}$ & $4.925 \mathrm{a}-\mathrm{e}$ & $38.60 \mathrm{~b}-\mathrm{g}$ & $5.667 \mathrm{~cd}$ & $3.000 \mathrm{de}$ \\
\hline & & Mix & $45.17 \mathrm{a}-\mathrm{f}$ & $20.00 \mathrm{bc}$ & $263.5 \mathrm{abc}$ & $111.3 \mathrm{~d}-\mathrm{k}$ & $4.320 \mathrm{a}-\mathrm{e}$ & 44.66 a-f & $5.833 \mathrm{~cd}$ & $2.333 \mathrm{e}$ \\
\hline & \multirow{5}{*}{0} & Control & $30.33 \mathrm{e}-\mathrm{i}$ & $21.33 \mathrm{abc}$ & $129.2 \mathrm{lmn}$ & 90.48 g-k & $6.255 \mathrm{ab}$ & $51.59 \mathrm{ab}$ & $6.500 \mathrm{abc}$ & $3.833 \mathrm{a}-\mathrm{e}$ \\
\hline & & G. intradices & $58.67 \mathrm{a}$ & $23.83 \mathrm{ab}$ & $114.3 \mathrm{mn}$ & $97.14 \mathrm{e}-\mathrm{k}$ & $5.907 \mathrm{a}-\mathrm{d}$ & $43.60 \mathrm{a}-\mathrm{f}$ & $6.500 \mathrm{abc}$ & $3.333 \mathrm{~b}-\mathrm{e}$ \\
\hline & & G. mossae & $57.00 \mathrm{ab}$ & $23.00 \mathrm{abc}$ & $132.2 \mathrm{k}-\mathrm{n}$ & $119.1 \mathrm{c}-\mathrm{k}$ & $4.755 \mathrm{a}-\mathrm{e}$ & $33.68 \mathrm{c}-\mathrm{g}$ & $6.500 \mathrm{abc}$ & $4.000 \mathrm{a}-\mathrm{e}$ \\
\hline & & G. hoei & $36.50 \mathrm{c}-\mathrm{i}$ & $21.33 \mathrm{abc}$ & $202.0 \mathrm{~d}-\mathrm{i}$ & $159.9 \mathrm{a}-\mathrm{h}$ & $6.255 \mathrm{ab}$ & $34.77 \mathrm{~b}-\mathrm{g}$ & $6.167 \mathrm{bcd}$ & 3.667 a-e \\
\hline & & Mix & $37.50 \mathrm{c}-\mathrm{i}$ & $23.17 \mathrm{ab}$ & $211.8 \mathrm{c}-\mathrm{h}$ & $163.1 \mathrm{a}-\mathrm{h}$ & $4.900 \mathrm{a}-\mathrm{e}$ & $40.38 \mathrm{a}-\mathrm{g}$ & $6.000 \mathrm{bcd}$ & $3.333 \mathrm{~b}-\mathrm{e}$ \\
\hline
\end{tabular}




\begin{tabular}{|c|c|c|c|c|c|c|c|c|c|c|}
\hline \multirow{10}{*}{110} & \multirow{5}{*}{25} & Control & $38.50 \mathrm{~b}-\mathrm{i}$ & $22.67 \mathrm{abc}$ & 257.6 a-d & $224.8 \mathrm{ab}$ & $5.907 \mathrm{a}-\mathrm{d}$ & $40.96 \mathrm{a}-\mathrm{g}$ & $7.000 \mathrm{abc}$ & $3.667 \mathrm{a}-\mathrm{e}$ \\
\hline & & G. intradices & $42.33 \mathrm{a}-\mathrm{g}$ & $23.83 a b$ & $220.0 \mathrm{~b}-\mathrm{g}$ & $211.3 \mathrm{ab}$ & $6.602 \mathrm{a}$ & $28.20 \mathrm{fg}$ & $6.667 \mathrm{abc}$ & $3.333 \mathrm{~b}-\mathrm{e}$ \\
\hline & & G. mossae & $29.67 \mathrm{e}-\mathrm{i}$ & $23.83 \mathrm{ab}$ & 247.0 a-e & $142.2 \mathrm{~b}-\mathrm{k}$ & $4.178 \mathrm{~b}-\mathrm{e}$ & $38.89 \mathrm{~b}-\mathrm{g}$ & $7.000 \mathrm{abc}$ & $4.667 \mathrm{a}-\mathrm{d}$ \\
\hline & & G. hoei & $52.83 \mathrm{a}-\mathrm{d}$ & $22.83 \mathrm{abc}$ & $231.9 \mathrm{~b}-\mathrm{f}$ & $194.9 \mathrm{abcd}$ & 4.897 a-e & $43.50 \mathrm{a}-\mathrm{f}$ & $6.167 \mathrm{bcd}$ & $4.167 \mathrm{a}-\mathrm{e}$ \\
\hline & & Mix & $30.17 \mathrm{e}-\mathrm{i}$ & $21.17 \mathrm{abc}$ & $237.6 \mathrm{~b}-\mathrm{f}$ & $152.6 \mathrm{a}-\mathrm{j}$ & 4.975 a-e & $36.76 \mathrm{~b}-\mathrm{g}$ & $6.500 \mathrm{abc}$ & $4.833 \mathrm{a}-\mathrm{d}$ \\
\hline & \multirow{5}{*}{50} & Control & $27.50 \mathrm{f}-\mathrm{i}$ & $20.67 \mathrm{abc}$ & $213.9 \mathrm{c}-\mathrm{h}$ & 181.5 a-e & $5.112 \mathrm{a}-\mathrm{e}$ & $48.78 \mathrm{abc}$ & $7.167 \mathrm{abc}$ & $4.667 \mathrm{a}-\mathrm{d}$ \\
\hline & & G. intradices & $41.83 \mathrm{a}-\mathrm{g}$ & $21.50 \mathrm{abc}$ & 246.0 a-e & $169.3 \mathrm{a}-\mathrm{h}$ & $5.800 \mathrm{a}-\mathrm{d}$ & $45.93 \mathrm{a}-\mathrm{f}$ & $6.000 \mathrm{bcd}$ & $3.667 \mathrm{a}-\mathrm{e}$ \\
\hline & & G. mossae & $36.50 \mathrm{c}-\mathrm{i}$ & $21.17 \mathrm{abc}$ & $212.9 \mathrm{c}-\mathrm{h}$ & $196.1 \mathrm{a}-\mathrm{d}$ & 5.447 a-e & $37.22 \mathrm{~b}-\mathrm{g}$ & $5.833 \mathrm{~cd}$ & $3.333 \mathrm{~b}-\mathrm{e}$ \\
\hline & & G. hoei & 23.00 ghi & $24.00 \mathrm{ab}$ & $245.1 \mathrm{~b}-\mathrm{f}$ & 166.4 a-h & $4.178 \mathrm{~b}-\mathrm{e}$ & $24.68 \mathrm{~g}$ & $5.833 \mathrm{~cd}$ & $3.667 \mathrm{a}-\mathrm{e}$ \\
\hline & & Mix & $27.33 \mathrm{f}-\mathrm{i}$ & $24.67 \mathrm{ab}$ & $224.1 \mathrm{~b}-\mathrm{g}$ & $180.2 \mathrm{a}-\mathrm{f}$ & $4.505 \mathrm{a}-\mathrm{e}$ & $37.90 \mathrm{~b}-\mathrm{g}$ & $6.500 \mathrm{abc}$ & $4.667 \mathrm{a}-\mathrm{d}$ \\
\hline \multirow{15}{*}{150} & \multirow{5}{*}{0} & Control & $38.50 \mathrm{~b}-\mathrm{i}$ & $23.83 \mathrm{ab}$ & $140.4 \mathrm{j}-\mathrm{n}$ & $97.57 \mathrm{e}-\mathrm{k}$ & $4.302 \mathrm{a}-\mathrm{e}$ & $45.05 \mathrm{a}-\mathrm{f}$ & $6.500 \mathrm{abc}$ & $4.333 \mathrm{a}-\mathrm{e}$ \\
\hline & & G. intradices & $42.33 \mathrm{a}-\mathrm{g}$ & $24.67 \mathrm{ab}$ & $157.7 \mathrm{~h}-\mathrm{n}$ & $85.55 \mathrm{~g}-\mathrm{k}$ & 3.825 cde & $29.26 \mathrm{efg}$ & $6.500 \mathrm{abc}$ & $3.667 \mathrm{a}-\mathrm{e}$ \\
\hline & & G. mossae & $41.50 \mathrm{a}-\mathrm{g}$ & $23.50 \mathrm{ab}$ & $194.0 \mathrm{e}-\mathrm{j}$ & 159.2 a-h & $4.213 \mathrm{~b}-\mathrm{e}$ & $34.38 \mathrm{~b}-\mathrm{g}$ & $6.333 \mathrm{bcd}$ & $4.333 \mathrm{a}-\mathrm{e}$ \\
\hline & & G. hoei & $32.50 \mathrm{e}-\mathrm{i}$ & $22.50 \mathrm{abc}$ & $233.7 b-f$ & $157.4 \mathrm{a}-\mathrm{i}$ & 5.140 a-e & $45.71 \mathrm{a}-\mathrm{f}$ & $6.833 \mathrm{abc}$ & $4.000 \mathrm{a}-\mathrm{e}$ \\
\hline & & Mix & $33.83 \mathrm{~d}-\mathrm{i}$ & $22.50 \mathrm{abc}$ & 134.9 k-n & $98.00 \mathrm{e}-\mathrm{k}$ & 4.830 a-e & $30.33 \mathrm{~d}-\mathrm{g}$ & $6.167 \mathrm{bcd}$ & $3.667 \mathrm{a}-\mathrm{e}$ \\
\hline & \multirow{5}{*}{25} & Control & $38.17 \mathrm{~b}-\mathrm{i}$ & $25.83 \mathrm{a}$ & $112.4 \mathrm{mn}$ & $92.71 \mathrm{f}-\mathrm{k}$ & 5.495 a-e & $39.63 \mathrm{a}-\mathrm{g}$ & $6.167 \mathrm{bcd}$ & $4.333 \mathrm{a}-\mathrm{e}$ \\
\hline & & G. intradices & $39.17 \mathrm{~b}-\mathrm{i}$ & $23.00 \mathrm{abc}$ & $138.9 \mathrm{j}-\mathrm{n}$ & $98.82 \mathrm{e}-\mathrm{k}$ & $5.867 \mathrm{a}-\mathrm{d}$ & 56.49 a & $8.000 \mathrm{a}$ & $4.000 \mathrm{a}-\mathrm{e}$ \\
\hline & & G. mossae & $33.83 \mathrm{~d}-\mathrm{i}$ & $23.17 \mathrm{ab}$ & $147.8 \mathrm{i}-\mathrm{n}$ & $100.1 \mathrm{e}-\mathrm{k}$ & 4.310 a-e & $39.99 \mathrm{a}-\mathrm{g}$ & $6.667 \mathrm{abc}$ & $4.000 \mathrm{a}-\mathrm{e}$ \\
\hline & & G. hoei & $21.33 \mathrm{i}$ & $21.17 \mathrm{abc}$ & $122.5 \mathrm{mn}$ & $69.88 \mathrm{jk}$ & 4.555 a-e & $37.68 \mathrm{~b}-\mathrm{g}$ & $6.500 \mathrm{abc}$ & $4.000 \mathrm{a}-\mathrm{e}$ \\
\hline & & Mix & $28.50 \mathrm{e}-\mathrm{i}$ & $23.00 \mathrm{abc}$ & $120.2 \mathrm{mn}$ & $65.41 \mathrm{k}$ & $5.082 \mathrm{a}-\mathrm{e}$ & 46.28 a-e & $5.833 \mathrm{~cd}$ & $3.000 \mathrm{de}$ \\
\hline & \multirow{5}{*}{50} & Control & $32.83 \mathrm{e}-\mathrm{i}$ & $20.83 a b c$ & $132.1 \mathrm{k}-\mathrm{n}$ & $83.18 \mathrm{~h}-\mathrm{k}$ & $5.572 \mathrm{a}-\mathrm{e}$ & $41.45 \mathrm{a}-\mathrm{g}$ & $6.167 \mathrm{bcd}$ & $4.167 \mathrm{a}-\mathrm{e}$ \\
\hline & & G. intradices & $42.33 \mathrm{a}-\mathrm{g}$ & $22.33 \mathrm{abc}$ & $117.9 \mathrm{mn}$ & $72.63 \mathrm{ijk}$ & 4.218 a-e & $48.52 \mathrm{abc}$ & $7.167 \mathrm{abc}$ & $4.333 \mathrm{a}-\mathrm{e}$ \\
\hline & & G. mossae & $38.50 \mathrm{~b}-\mathrm{i}$ & $22.00 \mathrm{abc}$ & $114.3 \mathrm{mn}$ & $99.33 \mathrm{e}-\mathrm{k}$ & $5.585 \mathrm{a}-\mathrm{e}$ & 46.66 a-e & $7.167 \mathrm{abc}$ & $4.333 \mathrm{a}-\mathrm{e}$ \\
\hline & & G. hoei & $42.33 \mathrm{a}-\mathrm{g}$ & $23.00 \mathrm{abc}$ & $108.1 \mathrm{n}$ & 182.4 a-e & $5.033 \mathrm{a}-\mathrm{e}$ & $41.25 \mathrm{a}-\mathrm{g}$ & $6.667 \mathrm{abc}$ & $3.333 \mathrm{~b}-\mathrm{e}$ \\
\hline & & Mix & $42.50 \mathrm{a}-\mathrm{g}$ & $21.17 \mathrm{abc}$ & $135.4 \mathrm{k}-\mathrm{n}$ & $87.47 \mathrm{~g}-\mathrm{k}$ & $6.477 \mathrm{ab}$ & $35.53 \mathrm{~b}-\mathrm{g}$ & $5.833 \mathrm{~cd}$ & $2.333 \mathrm{e}$ \\
\hline
\end{tabular}

Means with different letters in each column have significant difference at $5 \%$ probability level.

In this study, application of fertilizers, especially in dehydration, has a moderate effect on resistance to dehydration in plants. In irrigation after $110 \mathrm{~mm}$ of pan evaporation, most fertilizer combinations cause a significant increase in wet and biological yields. The most desirable fertilizer compounds with irrigation after $110 \mathrm{~mm}$ of pan evaporation in terms of wet and biological yields, were $25 \%$ of recommended dose of phosphorus fertilizer alone, $25 \%$ of recommended dose of phosphorus fertilizer combined with G. mossae, 50\% recommended phosphorus fertilizer dose with $G$. intraradices and $50 \%$ of recommended dose of phosphorus with $G$. hoei. Various studies have shown that phosphorus fertilizers can play an important role in increase in the resistance of plants to dehydration (Mirabello et al., 2013). On the other hand, mycorrhizal fertilizers can increase the water access of plants by increasing the absorption rate of the roots and reducing the impact of dehydration on plants (Sharma et al., 2015). It seems that in environmental conditions, moderate dehydration enhances the efficiency of phosphorous and mycorrhizal fertilizers in the growth of purple coneflower. The application of phosphorous fertilizer in moderate dehydration conditions increased biological yield of purple coneflower, which is probably due to reduced plant access to phosphorus in dehydrated conditions. Studies have shown that by reducing irrigation water, plant access to soil phosphorus decreases linearly; therefore, increase in the amount of phosphorus available in the soil through fertilization can play an effective role in increasing plant growth in dehydration conditions (Mirabello et al., 2013). Mycorrhizal fertilizers have also shown little impact in full irrigation conditions in different studies, while more effectiveness of this group of microorganisms has been obtained in dehydration conditions (Krishnakumar et al., 2013). This is because in dehydration conditions, the role of mycorrhizae becomes more pronounced by restricting plant access to growth resources such as fertilizers and water (Krishnakumar et al., 2013). In dehydrated conditions, mycorrhizae increase the 
absorption level and the amount of water absorbed by the plant (Sharma et al., 2015). However, researchers believe that in severe dehydration, the growth and activity of mycorrhizal can be reduced (Krishnakumar et al., 2013) and thus, these fertilizers cannot have a positive effect on plants in severe dehydration. In a study, Khalili et al. (2014) examined the effects of different levels of phosphorus fertilizer on Lepidium sativum herb. Based on the results of that study, application of phosphorous fertilizer increased the wet yield of peppermint significantly. However, in this study, there was a difference in the effectiveness of different species of mycorrhizal fungi in plant growth. Hedayati Mahdi Abadi et al. (2015) examined the effect of G. mossae and $G$. intraradices species on Caraway plant and observed that $G$. intraradices species did not have a significant effect on Caraway biomass, but $G$. mossae caused a significant increase in the biomass.

\section{Photosynthetic pigments}

The highest leaf carotenoid content of $6.6 \mathrm{mg}$ per gram of shoot fresh weight was obtained with the treatment of $25 \%$ of recommended dose of phosphorus fertilizer combined with $G$. intraradices in irrigation after $110 \mathrm{~mm}$ of pan evaporation and the lowest values of 3.4 and $3.2 \mathrm{mg}$ per gram were obtained in two treatment combination of $25 \%$ recommended phosphorus fertilizer. The dose was combined with a mixture of mycorrhizal fertilizers and $50 \%$ of recommended dose of phosphorus fertilizer combined with G. mossae with irrigation after $70 \mathrm{~mm}$ of pan evaporation. At irrigation after $70 \mathrm{~mm}$ of pan evaporation, fertilizer treatment including $25 \%$ of recommended dose of phosphorus fertilizer alone, $50 \%$ of recommended dose of phosphorus fertilizer alone and $50 \%$ of recommended dose of phosphorus fertilizer combined with $G$. intraradices increased leaf carotenoid content by $77.3,70.1$ and $78.3 \%$, respectively (Table 4). Chlorophyll content decreased under the influence of dehydration. At $25 \%$ of the recommended phosphorus fertilizer dose, by decreasing irrigation water from 70 to 150 $\mathrm{mm}$ pan evaporation, a decrease of $8.2 \%$ was observed in chlorophyll a content. In this study, a non significant increase was observed in chlorophyll content in only $25 \%$ of the recommended phosphorus fertilizer dose with reduced water irrigation after 70 to $150 \mathrm{~mm}$ of pan evaporation (Fig. 4). Dehydration reduces chlorophyll content by reducing the amount of chlorophyll produced and increasing its degradation (Rapparini et al., 2013). Chlorophyll a and carotenoid content were not affected by mycorrhiza but chlorophyll $b$ content was only affected by mycorrhiza which decreased it. Robinson et al. (2014) showed that the application of mycorrhiza increases the chlorophyll b content in sesame.

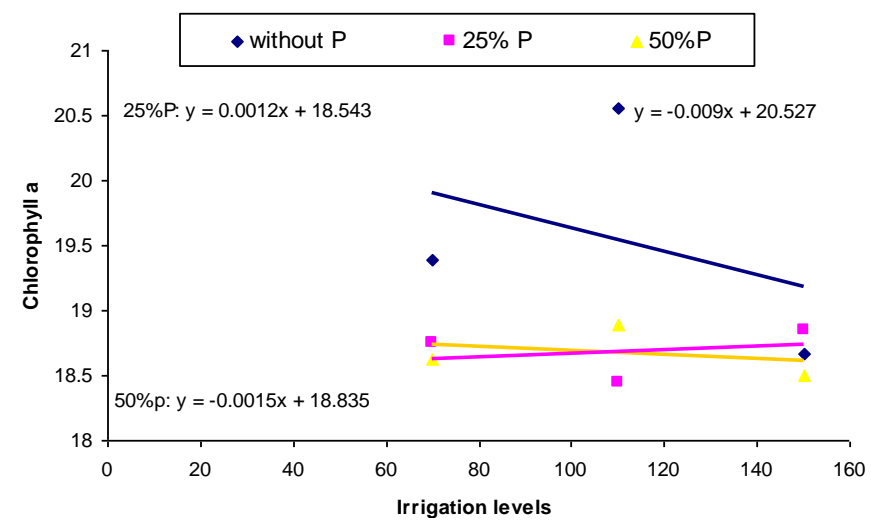

Figure 4. Effect of phosphorous on Chlorophyll a under irrigation levels 


\section{Plasma membrane stability}

In this study, in all the combinations of phosphorus fertilizer and mycorrhiza species, dehydration had no significant effect on plasma membrane stability and only in nonapplication of fertilizer, did reduction in irrigation water after 70 to $150 \mathrm{~mm}$ of evaporation caused a decrease of $33.7 \%$ in plasma membrane stability. In this study, in irrigation after $70 \mathrm{~mm}$ of pan evaporation, a number of combinations of phosphorus fertilizer and mycorrhiza had a significant effect on the stability of the plasma membrane. At this irrigation level, the treatments of G. mossae and G. hoei application alone, $25 \%$ of recommended dose of phosphorus fertilizer with G. hoei, $25 \%$ of recommended dose of phosphorus fertilizer with a mixture of fertilizers, $50 \%$ of recommended dose of phosphorus fertilizer alone and $50 \%$ of recommended dose of phosphorus fertilizer with $G$. intraradices increased the plasma membrane stability by 29.2, 41.7, 41.6, 30.6 and 28.7\%, respectively (Table 4).

\section{Stoma properties and relative water content}

According to the ANOVA results, traits of interactions between irrigation levels, phosphorous fertilizer levels and mycorrhiza species had a significant effect on aperture length and width (Table 2). In this study, the maximum aperture length of $8 \mu \mathrm{m}$ in the treatment combination was observed for $25 \%$ of recommended dose of phosphorus fertilizer with $G$. intraradices and irrigation after $150 \mathrm{~mm}$ of pan evaporation. The minimum $(4.8 \mu \mathrm{m})$ was associated with the application of $25 \%$ of recommended dose of phosphorus fertilizer with $G$. intraradices and irrigation after $70 \mathrm{~mm}$ of pan evaporation. In addition, the maximum aperture width of $5.6 \mu \mathrm{m}$ was observed in the mixture of mycorrhizal fertilizers alone with irrigation after $70 \mathrm{~mm}$ of pan evaporation and the lowest $(2.3 \mu \mathrm{m})$ was associated with the treatment of $50 \%$ recommended phosphorus fertilizer with a mixture of mycorrhizal fertilizers and irrigation after $150 \mathrm{~mm}$ of pan evaporation. In this study, a significant increase of $65 \%$ for the aperture length was observed only at $25 \%$ of recommended dose of phosphorus fertilizer with $G$. intraradices and reduced irrigation water at irrigation after 70 to $150 \mathrm{~mm}$ of pan evaporation. Moreover, except for the application of mixture of fertilizers alone or with $50 \%$ of recommended dose of phosphorus fertilizer, there was no significant difference between the irrigation levels in terms of aperture width in the fertilizer treatments. In the mixture of fertilizers alone, reducing irrigation water after 70 to $110 \mathrm{~mm}$ of pan evaporation decreased the aperture width by $2.4 \%$. In the treatment of a mixture of fertilizers with $50 \%$ of the recommended dose of phosphorus fertilizer in irrigation treatment after $150 \mathrm{~mm}$ of pan evaporation, the aperture width was $50 \%$ lower than the case of irrigation after $110 \mathrm{~mm}$ of pan evaporation (Table 4). Thus, in this plant, in the presence of mycorrhiza and conditions of dehydration, the aperture length increases and their width decreases, this will lead to higher carbon dioxide input and a decrease in transpiration.

In this study, except for $G$. intraradices application alone, relative water content was not affected by irrigation levels in the fertilizer treatments. In the application of $G$. intraradices alone, by reducing irrigation after 70 and $150 \mathrm{~mm}$ of pan evaporation, a decrease of $39.2 \%$ in relative water content was observed (Table 3). 


\section{Conclusion}

The results of this experiment prove that the application of mycorrhiza prevented a significant change in plant production due to dehydration by increasing leaf area and the production of flowering shoots, even under the conditions of less phosphorus fertilizer application. Changes in physiological traits, especially, the plasma membrane stability and aperture movements with the application of mycorrhiza, led to an increase in plant cellular power in the continuation of metabolic reactions and the production of essential oils also increased with mycorrhizal application even under extreme stress conditions. Reduction to at least, $50 \%$ of phosphorus consumption without significantly reducing the production of purple coneflower in terms of mycorrhiza application is more important in sustainable agriculture, even in the case of dehydration.

\section{REFERENCES}

[1] Allen, R. G., Pereira, L. S., Raes, D., Smith, M. (1998): Crop Evapotranspiration. Guidelines for Computing Crop Water Requirements. - FAO Irrigation and Drainage Paper 56. FAO, Rome.

[2] Arnon, D. I. (1949): Determination of chlorophyll concentration in leaf tissues of plants. - Plant Physiol. 24: 1.

[3] Arshad, M., Adnan, M., Ahmed, S., Karim Khan, A., Ali, I., Ali, M., Ali, A., Khan, A., Anwar Kamal, M., Gul, F., Ayaz Khan, M. (2016): Integrated effect of phosphorus and zinc on wheat crop. - American-Eurasian J. Agric. \& Environ. Sci. 16(3): 455-459.

[4] Asch, F., Andersen, M. N., Jensen, C. R., Mogensen, V. O. (2001): Ovary abscisic acid concentration does not induce kernel abortion in field-grown maize subjected to drought. - European Journal of Agronomy 15: 119-129.

[5] Bargali, K., Bargali, S. S. (2009): Effect of phosphorus nutrition on growth and mycorrhizal dependency of Coriaria nepalensis seedlings. - Nature and Science 7(6): 1924.

[6] Boomsma, C. R., Vyn, T. J. (2008): Maize drought tolerance: Potential improvements through arbuscular mycorrhizal symbiosis? - Field Crops Research 108: 14-31.

[7] Chevallier, A. (1996): The Encyclopedia of Medicinal Plants. - Dorling Kindersley Ltd. Publ., London.

[8] DaCosta, M., Huang, B. (2007): Drought survival and recuperative ability of bentgrass species associated with changes in abscisic acid and cytokinin production. - JASHS 132: 60-66.

[9] Das, D. (2015): A Contribution to the vesicular arbuscular mycorrhizal fungal status on twenty selected medicinal plants of Pandam forest in Darjeeling Himalaya, West Bengal, India. - Journal of Environmental Science, Toxicology and Food Technology 9: 61-71.

[10] Elbon, A., Whalen, J. K. (2014): Phosphorus supply to vegetable crops from arbuscular mycorrhizal fungi: a review. - Biological Agriculture \& Horticulture: An International Journal for Sustainable Production Systems 31(2): 73-90.

[11] Esmail, A. O., Sediq Yasin, H., Jalal Mahmood, B. (2014): Effect of levels phosphorus and iron on growth, yield and quality of flax. - Journal of Agriculture and Veterinary Science 7: 7-11.

[12] Evers, J. B., van der Krol, A. R., Vos, J., Struik, P. C. (2011): Understanding shoot branching by modelling form and function. - Trends in Plant Science 16: 464-467.

[13] Fazeli Rostampour, M., Yarnia, M. Rahimzadeh Khoee, F. Seghatoleslami, M. J., Moosavi, G. R. (2013): Physiological response of forage sorghum to polymer under water deficit conditions. - Agronomy Journal 105(4): 951-959. 
[14] Fletcher, A. L., Mooe, D. J., Scott, W. R. (2004): Leaf appearance and primordia initiation of 'Challenger' sweet corn in response to phosphorus. - Agronomy 4: 84-91.

[15] Habibzadeh, Y. (2015): Effects of phosphorus levels on dry matter production and root traits of chickpea plants in presence or absence of Arbuscular mycorrhizal fungi. Journal of Agricultural Science and Food Technology 1(1): 1-6.

[16] Hammond, J. P., White, P. J. (2008): Sucrose transport in the phloem: integrating root responses to phosphorus starvation. - Journal of Experimental Botany 59: 93-109.

[17] Hedayati Mahdi Abadi, B., Ganjali, H. R., Mobasser, H. R. (2015): Effect of mycorrhiza and phosphorus fertilizer on some characteristics of black cumin. - Biological Forum An International Journal 7(1): 1115-1120.

[18] Hosseini Valiki, S. R., Ghanbari, S., Akbarzadeh, M., Ghasempor Alamdari, M., Golmohammadzadeh, S. (2015): Effect of organic and chemical fertilizers on dry yield, essential oil and compounds on rosemary (Rosemarinus officinalis L.). - Biological Forum - An International Journal 7(1): 773-782.

[19] Khalil, S. E., Yousef, R. M. M. (2014): Interaction effects of different soil moisture levels, arbuscular mycorrhizal fungi and three phosphate levels on: i- growth, yield and photosynthetic activity of garden cress (Lepidium sativum L.) plant. - International Journal of Advanced Research 2: 723-737.

[20] Khan, M. S., Ahmad, E., Zaidi, A., Oves, M. (2013): Functional Aspect of PhosphateSolubilizing Bacteria: Importance in Crop Production. - In: Maheshwari, D. K., Aeron, A., Saraf, M. (eds.) Bacteria in Agrobiology: Crop Productivity. Springer, Berlin, pp. 237-263.

[21] Kotoky, R., Rabha, A., Kanjilal, P. B. (2015): Root yield and yield attributes of Aristolochia indica L. (Piperales: Aristolochiaceae) as effected by different spacing and fertilizer treatments in the North-East India. - Brazilian Journal of Biological Sciences 2: 235-243.

[22] Khalilvand, E., Yarnia, M. (2016): Effect of methanol foliar application on nutrient content and RWC of sugar beet under water deficit stress. - Bangladesh Journal of Botany 45(5): 1069-1074.

[23] Krishnakumar, S., Balakrishnan, N., Muthukrishnan, R., Ramesh Kumar, S. (2013): Myth and mystery of soil mycorrhiza: A review. - African Journal of Agricultural Research 8(38): 4706-4717.

[24] Kumar, R., Chandra, R. (2009): Influence of PGPR and PSB on rhizobium leguminosarum bv. viciae strain competition and symbiotic performance in Lentil. World Journal of Agricultural Sciences. 4(3): 297-301.

[25] Levitt, J. (1980): Response of plants to environmental stresses. Vol. II. - Academic Press. Inc., New York, pp. 279.

[26] Lu, L., He, C., Jin, Y. (2013): Effects off the applications of phosphorous and potasium fertilizers at different growth stages on the root growth and bioactive componds of Salvia militiorrhiza Bunge. - Ausralian Journal of Crop Science 7: 1533-1543.

[27] Mirabello, M. J., Yavitt, J. B., Garcia, B. A. D. M., Harms, K. E., Turner, B. C. B. L., Wright, S. J. (2013): Soil phosphorus responses to chronic nutrient fertilisation and seasonal drought in a humid lowland forest, Panama. - Soil Research 51: 215-221.

[28] Miyawaki, K., Matsumoto-Kitano, M., Kakimoto, T. (2004): Expression of cytokinin biosynthetic isopentenyltransferase genes in Arabidopsis: tissue specificity and regulation by auxin, cytokinin, and nitrate. - The Plant Journal 37: 128-138.

[29] Mohseni, M., Ardekani, M. R., Vazan, S., Paknezhad, F. (2015): The effect of mycorrhiza inoculation and azotobacter strains on the characteristics of the root of Cuminum Cyminum in agroecosystem without chemical materials. - J. Appl. Environ. Biol. Sci. 5(6): 96-104.

[30] Nazarli, H., Zardashti, M. R. (2010): The effect of drought stress and super absorbent polymer (a200) on agronomical traits of sunflower (Helianthus annuus L.) under field condition. - Cercetări Agronomice în Moldova 3(12): 5-14. 
[31] Pajooheshgar, R., Azizi, M., Nemati, H., Khorasani, R. (2015): Effect of organic substrate and phosphorus fertilization on seed, oil yields and composition of medicinal pumpkin (Cucurbita pepo var. styriaca). - Biological Forum - An International Journal 7(1): 593-601.

[32] Rapparini, F., Penuelas, J. (2013): Mycorrhizal Fungi to Alleviate Drought Stress on Plant Growth, Use of Microbes for the Alleviation of Soil Stresses. - In: Egamberdieva, D., Lugtenberg, B. (eds.) Use of Plant Growth-Promoting Rhizobacteria to Alleviate Salinity Stress in Plants. Vol. 1, pp. 21-42. Springer, New York.

[33] Robinson, J., Nithya, K., Ramya, R., Karthikbalan, B., Kripa, K. (2014): Effect of vesicular arbuscular mycorrhiza Glomus fasiculatum on the growth and physiological response in Sesamum indicum L. - International Letters of Natural Sciences 23: 47-62.

[34] Salvucci, M. E., Bartaa, C., Byersa, J. A., Canarini, A. (2010): Photosynthesis and assimilate partitioning between carbohydrates and isoprenoid products in vegetatively active and dormant guayule: physiological and environmental constraints on rubber accumulation in a semiarid shrub. - Physiologia Plantarum 140: 368-379.

[35] Sharma, N., Yadav, K., Cheema, J., Badda, N. and Aggarwal, A. (2015): Arbuscular mycorrhizal symbiosis and water stress: a critical review. - Pertanika J. Trop. Agric. Sci. 38(4): 427-453.

[36] Trindade, R. S., Paulo Araújo, A., Grandi Teixeira, M. (2010): Leaf area of common bean genotypes during early pod filling as related to plant adaptation to limited phosphorus supply. - R. Bras. Ci. Solo 34: 115-124.

[37] Yadav, A., Aggarwal, A. (2015): The associative effect of arbuscular mycorrhizae with Trichoderma viride and Pseudomonas fluorescens in promoting growth, nutrient uptake and yield of Arachis hypogaea L. - New York Science Journal 8(1): 101-108.

[38] Yordanova, R., Popova, L. (2007): Effect of exogenous treatment with salicylic acid on photosynthetic activity and antioxidant capacity of chilled wheat plants. - Gen. Appl. Plant Physiology 33(3-4): 155-170. 